\title{
Katılımcılık, Geribildirim ve Cevap Verebilirlik Boyutlarıyla Facebook'un Kurumsal İletişimde Etkileșimli Bir Mecra Olarak Kullanım Yetersizliği: Türkiye Menşeli Hava Yolları Şirketleri Üzerine Bir Değerlendirme
}

\author{
Inadequate Use of Facebook as an Interactive Tool with the \\ Dimensions of Participation, Feedback and Responsiveness for \\ Corporate Communications: A Survey on Airline Companies \\ with Domestic Capital in Turkey
}

Ezel TÜRK ${ }^{1 \oplus}$

${ }^{1} \mathrm{PhD}$., Res. Asst., İstanbul University, Faculty of Communication, Department of Public Relations and Advertising, Istanbul, Turkey

Sorumlu yazar/Corresponding author: Ezel Türk,

İstanbul Üniversitesi, İletişim Fakültesi, Halkla İlişkiler ve Tanıtım Bölümü, İstanbul, Türkiye E-posta/E-mail: ezel.kamcili@istanbul.edu.tr

Geliș tarihi/Received: 10.04.2018 Kabul tarihi/Accepted: 07.07.2018

Atıf/Citation: Türk, E. (2018). Katılımcılık, geribildirim ve cevap verebilirlik boyutlarıyla Facebook'un kurumsal iletişimde etkileşimli bir mecra olarak kullanım yetersizliği: Türkiye menşeli hava yolları şirketleri üzerine bir değerlendirme. Connectist: Istanbul University Journal of Communication Sciences, 55, 171-196.

https://doi.org/10.26650/CONNECTIST478936
ÖZ

İnternet ve Web tabanlı uygulamalarla hız kazanan teknolojik gelişmeler, iletişimin boyutunu değiştirmiş ve etkileşimli bir iletişim ortamını ortaya çıkarmıştır. Kuşkusuz bu durum kurumlarla hedef kitleleri arasındaki ilişkilerin geliştirilmesi için de yeni olanaklar sunmaktadır. Bugün sosyal medyanın özellikle de sosyal paylaşım ağlarının, hayatın her alanına nüfuz etmesiyle birlikte kurumla hedef kitleleri arasında daha etkileşimli bir iletişimin gerçekleşmesi mümkün hale gelmiştir. Bu nedenle sosyal paylaşım ağlarının başında gelen Facebook'un kurumsal iletişim aracı olarak etkileşimli bir şekilde nasıl kullanılması gerektiğinin belirlenmesi oldukça önem taşımaktadır. Bunun için de öncelikle Facebook'un kullanım amacının ve paylaşılan içeriklerin belirlenmesi gerekmekte daha sonra ise etkileşim unsurunun araştırılması gerekmektedir. Bu nedenle Türkiye'de faaliyet gösteren yerli sermayeli havayolu şirketlerinin Facebook kullanımlarının ortaya konulmasının amaçlandığı çalışma iki aşamadan oluşmaktadır. Çalışmanın ilk aşaması olan, Facebook'un kurumlar tarafından daha ziyade tanıtım ve promosyon amaçlı olarak kullanıldığına yönelik tespit, "Türkiye'deki havayolu şirketlerinin Facebook'u kurumsal amaçlı olarak kullanımı" başlığı ile araştırmacı tarafından yayımlanmıştır (Türk, 2018). Bir takip çalışması niteliğinde olan, çalışmanın ikinci kısmını oluşturan bu araştırmada ise Facebook'un etkileşimli bir mecra olarak kullanılmasındaki yeterliliğin tespit edilmesi amaçlanmaktadır. Altı hava yolu şirketinin kurumsal Facebook hesapları; nitel araştırma yöntemlerinden içerik analizi tekniği ile analize tabi tutulmuşve toplanan veriler betimsel istatistiğe başvurma yoluyla değerlendirilmiştir. Buna göre; kurumların paylaştıkları içeriklerle kullanıcıları katılımcılığa teşvik etmede, onlara sorular sorarak geri 
bildirim döngüsünü sağlamada ve onlardan gelen soru ve yorumlara cevap vermedeki yetersizliklerinden dolayı Facebook'u etkin ve yeterince etkileşimli bir mecra olarak kurumsal iletişimde kullanamadıkları sonucuna ulaşılmıştır. Anahtar Kelimeler: Etkileşim, katılımcılık, geribildirim, cevap verebilirlik, Facebook

\section{ABSTRACT}

Technological developments have grown quickly, thanks to the internet and web-based applications. They have changed the means of communication and created an interactive environment that enables new ways of developing relationships between corporations and their target groups. Today, social media, especially social networking sites, have penetrated into every area of social life, creating even more interactive communication between corporations and target groups. Thus, it is useful to determine how Facebook, the largest and most popular social networking site, can be best used by corporations as an interactive medium. For that reason, firstly the purpose of Facebook use and contents of Facebook posts need to be examined and then the interactivity component should be researched. That is why the study, which aims to examine Facebook use by airline companies with domestic capital operating in Turkey, has been arranged in two parts. The first part of the study, entitled "A content analysis of Facebook posts by airlines companies", was published by the researcher and revealed that Facebook was mostly used for publicity and promotion (Türk, 2018). As a followup study, this study is the second part, whose aim is to determine whether Facebook is used interactively. The Facebook accounts of six different airline companies were analyzed through a content analysis technique and the data colleted were analyzed through descriptive statistics. The results reveal that corporations are unable to use Facebook adequately for corporate communications, since they are ineffective in encouraging users to participate in Facebook with the contents they share, to provide a cycle of feedback by asking questions and to respond to the questions and comments of the users.

Keywords: Interactivity, participation, feedback, responsiveness, Facebook

\section{EXTENDED ABSTRACT}

Internet and web-based applications have created an interactive environment for communication that enables new means of developing relationships between corporations and their target groups. Today, social media has penetrated into every aspect of life, creating more interactive communication between corporations and their target groups. Thanks to social media, especially social networking sites, target groups no longer consider themselves just as consumers and no longer receive corporate messages passively. That is why it is valuable to determine how Facebook can be best used by corporations as an interactive medium. To reveal this, the purpose of Facebook use and contents of Facebook posts need to be examined first and then the interactivity should be studied. For that reason the study has been designed in two parts, one of which was published by the researcher and revealed that Facebook was mostly used for publicity and promotion. In particular, product and service promotion rose into prominence together with campaigns and special offers (Türk, 2018).

Besides publicity and promotion, social networking sites can be used for building and retaining relationships with target groups through their interactive structure. It is 
worthwhile to determine how Facebook, having the leading role among social networking sites, can be used by corporations as an interactive medium. That is why this study, as a follow-up study and the second part of the study, aims to reveal the use of Facebook as an interactive tool by airline companies with domestic capital operating in Turkey. It attempts to reveal whether these corporations take advantage of Facebook for corporate communication by using it in an interactive way including participation, responsiveness and feedback. Specifically, the study aims to answer these two questions: 1) Do corporations use Facebook interactively and encourage users to participate in Facebook with the content they share? 2) Are they able to provide a cycle of feedback by asking questions and are they able to respond to the questions and comments of the users?

Among these corporations, the selection of airline companies with domestic capital is very important in order to show whether they are using Facebook in a truly intensive way, according to the data of www.socialbakers.com, leveraging the largest social media data-set in the industry. The Facebook accounts of six different airline companies: AnadoluJet, Atlasglobal, Onur Air, Pegasus Airlines, SunExpress, and Turkish Airlines, were analyzed through a content analysis technique. After the accounts were identified, their posts for December 2016 were encoded and reviewed according to a schema developed to measure interactivity. While the first part of the study analyzed the contents and the types of the Facebook posts, this (second) part analyzed the interactivity designed as two categories for a content analysis, one of which is participation and feedback, and the other is responsiveness to users' comments and questions. After a 60-min training session, two coders encoded six corporations' posts for the month of December 2016. Using Cronbach's Alpha, the intercoders met intercoder reliability $(a=0.650)$. Data from the variables identified in the data sheet were analyzed using the SPSS 24.0 program and were evaluated through descriptive statistics.

The results revealed that corporations have used Facebook inadequately within the scope of interactivity for corporate communications. The airlines studied failed to provide participation on their corporate Facebook accounts, leading to a failure to fulfill the participation component of interactivity. Nor did the corporations ask users any questions about their products, services, or the users' preferences for providing feedback, which is the other component of interactivity. Communication via feedback and responses are other significant components in ensuring interaction. Since 
corporations responded to a mere one-fourth of their user comments and questions, it can be asserted that they did not adequately communicate with their target groups. Responses given by corporations were informative, however, which indicates that people who seek information from the companies were sincerely considered. The companies tried to meet the need for information through Facebook. They also attempted to provide answers to either solve problems on Facebook or direct them to the relevant units for professional support.

Since they are ineffective in encouraging users to participate via Facebook, to provide a cycle of feedback and to be responsive on Facebook, which social media platform is used interactively? There is no doubt that social networking sites are popping up by the day, thanks to mobile technologies, and it is clear that in the near future this trend will continue even more intensively. Therefore, future research could investigate which social media platform is used to engage with target groups in an interactive way. Likewise, future studies should also find out how Facebook can be best used for engagement, not only by providing feedback and responsiveness but also encouraging participation. Only if corporations appreciate the use of Facebook will they be able to interact and communicate effectively with target groups. Thus, building and maintaining positive relationships between corporations and target groups will become more feasible. 


\section{GíRiş}

1990'lı yıllardan itibaren hayatımıza girmiş olan 'etkileşim' ve 'etkileşimlilik' kavramları farklı tanımları da beraberinde getirmiş ve iletişim teknolojilerinde yaşanacak olan gelişmelere ışık tutmaya başlamıştır (Quiring, 2009, p. 899). İnternet ve bilgisayar teknolojisi için kullanılan etkileşim kavramı bugün sosyal medya için kullanılmakta ve sosyal medya araçlarına gönderme yapmaktadır. Çünkü sosyal medya sayesinde bugün hedef kitleler; kurumların kendilerine ilettikleri mesajı edilgen bir şekilde alan tüketici konumundan sıyrılarak çevrimiçi ortamlarda kendi fikirlerini dile getiren ve konuşma ortamlarına katılan etkin bir konuma gelmişlerdir (Men \& Tsai, 2014, p. 419). İnsanlar sosyal medya üzerinden özellikle de sosyal paylaşım ağlarından kurumlara rahatlıkla erişmekte ve iletişime geçebilmektedir; bu da kurumla hedef kitle arasındaki iletişimin ve paylaşımın yeni biçimlerde gerçekleşmesine yol açmaktadır.

Sosyal medya kurumla hedef kitleleri arasında doğrudan bir iletişim imkânı sunduğu için iki yönlü iletişimin gerçekleşmesini daha olanaklı hale getirirken (Hether, 2014; Wright \& Drifka, 2009); geri bildirimlerin anında alınmasına da olanak tanımakta (Lipsman, Graham, Mike, \& Sean, 2012, p. 41) ve bu nedenle geleneksel iletişim araçlarına göre çok daha fazla etkileşimli bir mecra olarak ortaya çıkmaktadır. Özellikle Facebook, Twitter, YouTube gibi sosyal paylaşım ağları; kullanıcılar arasındaki etkileşimi en yüksek seviyede sağladığı için kurumların hedef kitleleriyle olan iletişiminde çok daha etkili ortamlar haline gelmişlerdir.

Etkileşim, günümüzün halkla ilişkiler anlayışını oluşturan iki yönlü iletişimin sağlanması ve karşılıkı ilişkilerin inşa edilmesi için gerekli en önemli unsurlardan biridir (Avidar, 2013, p. 440). Ayrıca iki yönlü iletişim ve diyalog kavramları üzerine literatürde pek çok çalışma yapılmıştır (Breakenridge, 2008; Bortree \& Seltzer, 2009; Grunig, 2002, 2009; Kent \& Taylor, 1998, 2002; McAllister-Spooner, 2009; Theunissen \& Wan Noordin, 2012; Waters, Burnett, Lamm, \& Lucas, 2009); ancak etkileşim üzerine yapılan çalışmaların yetersiz kaldığı görülmektedir. Oysa ki etkileşim unsuru (cevap verebilirlikle birlikte) iki yönlü iletişimin ve diyalogun sağlanması için gerekli en temel koşulu yerine getirmektedir (Avidar, 2013, p. 440).

Gerek akademisyenler gerekse halkla ilişkiler uygulayıcıları; etkileşim aracılığıyla kurum ve hedef kitle arasındaki iletişimin kurulmasında, sosyal medyanın önemli bir yeri olduğuna dair hem fikir olmalarına rağmen; sosyal medya üzerindeki etkileşim 
konusunda yeterli çalışmaların yapılmadığı görülmektedir (Waters \& Williams, 2011, p. 354). Var olan çalışmalar da etkileşimi kurumun cevap verebilirliği algısı üzerinden ele almakta (Vendemia, 2017); etkileşimden faydalanarak sosyal medya içeriğinin etkinliğini ölçmekte (Watkins, 2017) veya etkileşimin örgütsel halkla ilişkiler niteliğine olan etkisini ele almaktadır (Saffer, Sommerfeldt, \& Taylor, 2013).

Sosyal medyanın en yaygın olarak kullanılan ortamlarından olan sosyal paylaşım ağları, hem kurumlara hem de hedef kitlelerine birbirleriyle pek çok farklı şekilde iletişim ve etkileşim içinde olmalarına olanak sağlamaktadır. Sosyal paylaşım ağları kurumun görünürlüğünü ve içeriğinin kalıcılığını arttıracağı için halkla ilişkiler çabalarının bu platformlara taşınması açısından oldukça önemlidir (Vendemia, 2017, p. 100). Ayca kurumun diğer tüm hedef kitleleriyle farklı türde gerçekleştireceği etkileşimlere dayalı bir iletişim anlayışını benimsemesi, kurumu hedef kitlenin nezdinde olumlu olarak algılanmasını da sağlayacaktır.

Yapılan çalışmalarda, sosyal ağların kurumsal amaçlı olarak halkla ilişkiler çabalarının bir parçası olarak kullanıımaya başlandığı saptanmıştır. Bu çalışmanın birinci aşaması olan çalışmada; sosyal paylaşım ağlarından en yaygın olarak kullanılan Facebook ortamı seçilmiş ve Facebook'un kurumlar tarafından tanıtım amaçlı kullanıldığı saptanmıştır. Özellikle de hizmet ve ürün tanıtımın ön plana çıktığı, bununla birlikte kampanya ve promosyonların da tanıtımlarının yine bu mecradan yapıldığı görülmektedir (Türk, 2018). Ancak tanıtım amaçlı kullanımının yanı sıra; sosyal paylaşım ağlarının etkileşimi sağlayan yapısından faydalanarak hedef kitlelerle ilişkileri geliştirmek ve sürdürmek de mümkündür. Bu nedenle bir devam araştırması olan bu çalışmanın amacı, sosyal medyanın kurumlar tarafından uygulamadaki örneklerinin ortaya konmasıdır. Bunun için de Facebook'un etkileşimli bir mecra olarak kurumlar tarafından kullanımının ele alınması böylece hedef kitleleriyle olan ilişkilerinin ortaya konması amaçlanmaktadır. Bu amaç doğrultusunda Türkiye menşeli havayolu şirketlerinin kurumsal Facebook hesaplarından yürüttükleri iletişim faaliyetlerinin hedef kitleleriyle olan etkileşiminin ortaya konması amaçlanmıştır.

\section{Sosyal Paylaşım Ağları ve Facebook}

Tüm dünyada gittikçe yaygınlaşan ve en çok kullanılan sosyal medya araçlarılyla birlikte sosyal paylaşım ağları da hızlı bir şekilde yaygınlaşmaktadır. Sosyal paylaşım ağları; herkese açık ya da yarı açık profiller sunarak katılımcıların bir sistemin içine 
dahil olmasını ve diğer kullanııılarla ilişkilerini buradan sürdürmelerini sağlamaktadır (Lange, 2007, p. 362). Sosyal ağların temel felsefesinde insanlarla bağlantı kurmak yatmaktadır. Paylaşılan içeriklerin ve iletilerin başkaları tarafından yeniden yayınlanması veya durum güncellemelerine yorum yapılması o kişinin etkinlik akışında görüldüğü için ne kadar çok kullanıcı içerikle bağlantı kurarsa o kadar çok kişinin arkadaş topluluğu arasında yayılmış olmaktadır ve böylece çok sayıda insana erişmektedir (Handley \& Chapman, 2011, p. 163).

Her ortamın kendine özgü bir yapısı ve işleyişi olmasına rağmen; sosyal paylaşım ağlarının ortak özellikleri anlık mesajlar ve iletiler gönderebilme, fotoğraf, video gibi içerikleri kişisel profilde paylaşabilme, diğer kullanıcılarının paylaşımlarına yorum yazabilme ve başkalarının içeriklerini paylaşabilmesidir. İnsanlar sosyal ağlarda siyasi, dini ve mesleki görüşleri de dahil olmak üzere kendi kişisel bilgilerini paylaşabilmektedir (Adamson, 2008). Sosyal paylaşım ağlarının geleneksel iletişim araçlarından ayrılan özelliği, kullanııların kendi içeriklerini kendilerinin oluşturmasıdır. İçerikleri kontrol edebilme ve katkıda bulunabilme imkânı sunduğu için sosyal paylaşım ağları kısa bir sürede yaygınlaşmıştır. Facebook, Twitter, MySpace ve YouTube gibi sosyal paylaşım ağları tüm dünyada olduğu gibi Türkiye'de de en çok kullanılan ağlar arasında yer almaktadır.

Haziran 2017 verilerine göre günlük aktif kullanıcı sayısı neredeyse bir buçuk milyara (1.32 milyar) yaklaşan Facebook (Facebook, 2017a); 2004 yılında kurulduğunda sadece Harvard Koleji öğrencilerinin kendi aralarındaki iletişimi sağlamak amacını taşımaktaydı (Hopkins, 2012, p. 133). Bugün bu amacını çoktan aşarak, tüm dünyanın en çok kullanılan sosyal paylaşım ağı haline gelmiştir.

Türkiye'de yapılan bir araştırmaya göre (Şener, 2009); Türkiye'deki Facebook kullanıcıları yaşa, cinsiyete ve sosyo-ekonomik duruma göre değişiklik göstermesine rağmen; Facebook kullanıııların gündelik hayatlarının bir parçası haline gelmiştir. Türkiye'de Facebook kullanımında eğlence, bilgilenme/arkadaşlık, rahatlama/sosyal kaçış ve sosyal etkileşim olmak üzere dört unsur öne çıkmaktadır (Karakoç \& Gülsünler, 2012). Facebook kullanım sebeplerinin en başında eğlence motivasyonu olması gelirken bilgilenme/arkadaşlık unsuru ikinci sırada yer almaktadır. İnsanlar, boş zaman geçirmek ve eğlenmek amacının yanı sıra var olan arkadaşlıkları sürdürmek için (Şener, 2009) ve günlük hayatta takip edemedikleri birçok konuyu takip etmek ve bilgi edinmek için (Karakoç \& Gülsünler, 2012) Facebook'u kullanmaktadırlar. 
Facebook'un kullanııılarına sunduğu profil sayfaları ile kullanıcılar kişisel bilgilerini ve arkadaşlarını kendileri belirlemekte; paylaşacakları fotoğraf, video gibi içerikleri kendi ilgi ve istekleri doğrultusunda seçip profillerinde paylaşabilmektedirler. Bunun yanı sıra birbirlerine mesajlar gönderebilmekte ve sosyal gruplara katılarak etkin bir şekilde burada yer alabilmektedir (Hopkins, 2012, p. 133). Facebook'un bir diğer özelliği olan Sayfalar (Pages), sıradan insanların yanı sıra; sanatçılar, kamuya mal olmuş kişiler, kurumlar ve sivil toplum örgütlerinin de Facebook üzerinde yer almasını ve insanlarla doğrudan iletişim kurabilmesini sağlamaktadır. Bir Sayfa'yı beğenen kullanıcı, o Sayfa'dan gelen tüm yeni içerikleri ve güncellemeleri kendi Haber Akışı́nda (News Feed) görebilmektedir. Sayfa'da yer alan içerikler (post) kullanıcılar tarafından beğenildiğinde veya yorum yapıldığında, o Sayfa'nın bilinirliği artmakta ve daha fazla kişiye ulaşmaktadır (Facebook, 2017b).

Sosyal medyanın temelini oluşturan kullanıııların ürettiği içerik, Facebook ortamı için de geçerli olup oldukça önem taşımaktadır. Her ne kadar Sayfa'lardaki içerik kurumlar tarafından oluşturulsa da, bu içeriklere kullanıcıların yorumlarda bulunması içeriğin ulaştığı kişi sayısını doğrudan etkilemekte ve arttırmaktadır. Çünkü o kullanıcının kendi arkadaş listesindeki diğer kullanıcılar da bu içerikleri görebilmektedir. Bunun yanı sıra, hem fotoğraf hem de videoların paylaşılmasında ve çok sayıda kullanıcıya ulaşmasında da Facebook öne çıkan bir mecra haline gelmektedir.

\section{Etkileşim Kavramı ve Sosyal Paylaşım Ağları}

1990'ı yıllardan itibaren telaffuz edilen etkileşim kavramının sahip olduğu iki anlamdan ilki teknolojinin kendisiyle ilişkilidir. Kullanıcıların bilgisayar ortamında gerçekleştirdikleri işlemlere bilgisayarın cevap verebilme kapasitesi, etkileşimin teknolojik boyutunu ifade etmektedir. Etkileşimin diğer anlamı da iki kişi veya iki nesnenin birbirlerini etkilemesi ve böylece birlikte çalışma sürecinin ortaya çıkarmasıyla ilişkilidir Oxford Dictionaries, 2017). Birlikte çalışma süreci ile kast edilen şey karşıııklı bir işleyişin olmasıdır.

Teknolojik sistemler, kullanıcı algısı ve süreç olmak üzere etkileşim üzerine yapılan akademik tanımlar ise; temelde üç farklı olgu üzerinden ele alınmaktadır (McMillan \& Hwang, 2002; Rafaeli \& Ariel, 2007; Quiring, 2009). Teknolojik sistemlerin bir özelliği olan etkileşim; sistemin kullanıcıya tepki verme zamanına göre ele alınmaktadır. 
Sistemin kullanıc girdilerine cevap verebilme durumuna bakılmaktadır (Quiring, 2009, p. 901); böylece kullanıcı kontrolü ve iki yönlü iletişim gibi genel özellikler ya da web sitelerinin (günümüzde sosyal medyanın) belirli özelliklerine odaklanılarak etkileşimin tanımı yapılmaktadır (McMillan \& Hwang, 2002, p. 30). Teknolojinin kendi sistemsel yapısıyla ilgili olduğu için her sosyal medya ortamının etkileşim durumu aynı olmamaktadır.

Bir diğer bakış açısı, kullanıcıların algıları ve duyularının bir sonucu olarak ortaya çıkan etkileşim olgusudur. Bu bakış açısına göre teknolojik sistemler etkileşim potansiyelini kullanıcılara sunmaktadır. Ancak kullanııların bundan yararlanması için bu etkileşim potansiyelini kavramaları ve algılamaları gerekmektedir (Kiousis, 2002; Newhagen, 2004; Quiring, 2009; ). Belirli bir iletişim aracını kullanan kişilerin kendi deneyimleri üzerinden ve bu aracın etkileşim seviyesine şekillenen beklentileri üzerinden o iletişim aracının etkileşimliliğini değerlendirmektedirler (Ariel \& Avidar, 2015, p. 22). Daha açık bir ifadeyle; oldukça öznel bir yaklaşım içeren etkileşim olgusu kullanıcı deneyimlerine ve aktarımlarına dayanmaktadır.

Algılara dayalı etkileşimin önceden değerlendirme ve sonradan değerlendirme olmak üzere iki boyutu bulunmaktadır. Gelecekteki etkileşimlerin farkına varılmasına dayalı olan önceden değerlendirme; daha önceki deneyimlerden yola çıkarak benzer süreçler yaşandığındaki beklentileri ifade etmektedir. Bu beklentiler teknolojik ortamın kendisinden ortaya çıkmakta, kişisel ve öznel tahminlere dayalı olarak gerçekleşmektedir. İkinci boyut olan sonradan değerlendirme, sürecin sonrasında kullanıcı tarafından deneyimlerin gerçekleşmesi sonucunda ortaya çıkmaktadır. Bu tür değerlendirme kullanıcının teknolojik bilgisine, sürece dair dikkatine ve sürece dâhil olmasına dayanmaktadır (Ariel \& Avidar, 2015, p. 22). Özellikle reklam ve pazarlama alanındaki araştırmalar etkileşimin algılanmasına odaklanmaktadır. Tüketiciyi araştırmanın temeline alarak; çoklu ortamlar, hız, iki yönlü iletişim için kontrol unsurları gibi farklı değişkenlerin, tüketici algısını ya da deneyimini iletişim aracının etkileşim seviyesine göre nasıl etkilediğini analiz etmektedir (McMillan \& Hwang, 2002).

Etkileşim kavramına yönelik getirilen bir diğer tanımlamanın ortak noktasında iletişim süreci bulunmaktadır ve etkileşim, iletişim sürecinin bir unsuru olarak görülmektedir (Kiousis, 2002; McMillan \& Hwang, 2002; Quiring, 2009). Süreç bakış açısıyla ele alındığında, etkileşimin temel unsurları olan cevap verebilirlik (responsiveness) ve karşıllıklı değiş tokuş (interchange) gibi unsurlar ön plana 
çıkmaktadır (McMillan \& Hwang, 2002, p. 30). Etkileşim; iletişim sürecinde yatmakta ve katılımcılar arasında iletişimin karşııklı değiş tokuşu olduğu zaman gerçekleşmektedir (Quiring, 2009, p. 901). Illetişimin değiş tokuşu ile anlatılmak istenen; karşılıklı işleyen bir iletişim sürecinin olması ve her iki taraf arasında karşılıklı bir iletişim akışının gerçekleşmesidir.

Ancak Rafaeli'ye (1988, p. 121) göre, her iletişim etkileşimi içermemektedir. Kaynaktan gelen mesaja alııının vereceği geribildirimle birlikte her iki taraf arasında gerçekleşen geribildirimden etkileşim ortaya çıkmaktadır. Rafaeli'nin bahsettiği geribildirim aslında iki taraf arasındaki değiş tokuşun olmasıdır. Bu nedenle gerçek anlamda etkileşimin oluşması için iki taraf arasında bir değiş tokuşun diğer bir ifadeyle geribildirimin olması gerekmektedir. Ancak etkileşimi sadece bir 'değiş tokuş' olarak görmeyen Richards'a göre (2006, p. 533) ise; etkileşim aynı zamanda içeriğin oluşturulmasıdır. Iç̧eriğin kimin tarafından oluşturulduğu önemli olarak görülmektedir.

İletişimin tarafları arasında ortaya çıkan geribildirim döngüsünün sonucunda iki yönlü iletişim gerçekleşmektedir. Karşılıklı bir konuşma ortamının olduğu iki yönlü iletişimde; mesajı alan taraf, iletişimin kontrolünü elinde tutmaktadır. Etkileşimli bir iletişim ortamında tüm katılımcılar mesajların gönderilmesi ve alınması imkânına sahip olduğu için, mesajı alan taraf iletişim sürecinin kontrolünü elinde tutmaktadır (McMillan, 2002, p. 272). Kent ve Taylor'a (1998) göre iki yönlü iletişimin diyaloga dayalı bir şekilde gerçekleşmesi gerekmektedir. Ancak bu sayede hedef kitlelerle karşııklı anlayış temelinde ilişkiler kurulması olanaklı hale gelmektedir (Grunig \& Grunig, 1992, p. 298).

Etkileşimi iletişim sürecinin temel unsuru olarak gören yaklaşıma göre; karşlıklı değiş tokuşla birlikte cevap verebilirlik unsuru da ön plana çıkmaktadır. Cevap verebilirlik kavramı, karşı taraftan gelecek herhangi bir bilgi talebine karşı istekli ve hızı bir şekilde cevap verilmesini ifade etmektedir (Kelleher \& Miller, 2006). Cevap verebilirliği; her konuşmacının diğerine cevap verme olasılığı, verilen cevapların alakalı olması ve karşı tarafın talebine uygun özenli cevapların verilmesi olarak tanımlamak mümkündür (Davis, 1982).

Kuşkusuz, etkileşimi sürdürmede cevap verebilirliğin önemli bir yeri bulunmaktadır ve bu iki kavram birbirleriyle yakından ilişkilidir. Iletişim içerisindeki taraflar birbirlerine cevap verebildikleri kadar etkileşim içerisinde bulunabilmektedirler 
(Avidar, 2013; Rafaeli, 1988). İletişimin etkin bir şekilde sürdürülmesi etkileşimin de sürdürülmesi anlamına gelmektedir.

Etkileşimin sürdürülmesini olanaklı kılan cevap verebilirlik, aynı zamanda etkileşim amaçlarının da gerçekleşmesini olanaklı kılmaktadır. Cevap vermek, soru soranın (diyalogu başlatanın) amacına yardımcı olabildiği gibi bazen hiçbir yardımı da olmamaktadır. Ancak hiçbir şekilde cevap vermemek kesinlikle bu sürece zarar vermektedir. Aynı şekilde alakasız ya da yetersiz veya abartılı yanıtlar da etkileşim amaçlarının gerçekleşmesine daha az katkıda bulunmaktadır. Diğer yandan alakalı ve yeterli bir şekilde cevap verildiğinde; belirli bir konu üzerinde bilgi edinmek, tartışmak, karşılıklı konuşmak gibi etkileşimin amaçlarının gerçekleşmesini olanaklı kılmaktadır. Bu nedenle cevap verebilirlik kesinlikle etkileşimin amaçlarının gerçekleşmesine yardımcı olmaktadır (Davis, 1982, p. 88). Burada dikkat edilmesi gereken bir diğer konu, katılımcıların, sosyal paylaşım ağları üzerinden olumsuz eleştirilerini diğer ortamlara göre daha rahat biçimde paylaşabildikleridir (Tufan, 2014, p. 93). Olumsuz yorumlara dayalı etkileşim sürecini yönetmek, çok daha özenli bir yaklaşım gerektirmektedir.

Cevap vermede sürekli başarısız olmak ya da hiç cevap vermemek konuşmanın akışını olumsuz olarak etkilemektedir. Her ne kadar vakitlice cevaplar verilmesi önemli bir unsur olsa da cevabın niteliği ve mizacı da etkileşimi etkilemekte ve alakasız cevaplar vermek iletişimin sekteye uğramasına neden olmaktadır (Davis, 1982, p. 87; Vendemia, 2017, p. 101). Bu nedenle sadece cevap vermiş olmak için değil; karşı tarafın beklentileri doğrultusunda tatmin edici cevaplar vermek, iletişimin sürdürülmesi ve dolayısıyla etkileşimin amaçlarının gerçekleşmesi için oldukça önemlidir.

Etkileşim içerisinde gerçekleşen cevap verebilirliği etkileyen dört unsur bulunmaktadır. Bunlar; karşı tarafa gerekli ilgi ve özenin verilmesi, karşılıklı iletişimin tam olarak anlaşılması, yeterli yanıtların verilebilmesi için gerekli donanıma sahip olunması ve cevap vermeye istekli olunmasıdır. Illk üç unsur; kişinin cevap verebilirlik için kapasitesine bağlıyken, istekli olmak bir tercih meselesi olmaktadır çünkü cevap vermenin sonucunda karşılığını alarak takdir edilmek cevap verme isteğini doğrudan etkilemektedir (Davis, 1982, p. 91).

Kurumlar açısından cevap verebilir olmaları demek, hedef kitleden gelecek şikâyet ve bilgi taleplerine karşı, kurumların zaman kaybetmeden cevap vermeye istekli 
olmaları demektir (Kelleher \& Miller, 2006). Kurumların, paydaşlarına ve hedef kitlelerine cevap verebilir durumda olmaları hedef kitlelerin kuruma yönelik bakış açısını ve izlenimini olumlu yönde etkilemektedir (Davis, 1982, p. 88).Halkla ilişkiler açısından ele alındığında cevap verebilirlik kavramı; bireylerin sorularına ve yönlendirmelerine yönelik kurumun cevap verebilmesidir.

Görüldüğü gibi tek bir tanımı bulunmayan etkileşim kavramı, mesajın içeriği ile teknolojinin kendi yapısına odaklanan farklı görüşlerin sonucunda farklılık göstermektedir (Kiousis, 2002, p. 357). Özellikle bilgisayar teknolojilerinin ve internetin ortaya çıkıp gelişmesiyle birlikte, etkileşim kavramı web sitelerinin özellikleriyle ele alınmaya başlanmıştır (Freeman \& Chapman, 2012; Kent, Taylor \& White, 2003; Reber \& Kim, 2006; Yang \& Taylor, 2010). Bugün ise, sosyal medya ile özdeşleştirilen etkileşim kavramı; sosyal paylaşım ağları ve sosyal medya araçları sayesinde bilginin kontrol edilebilmesini ve etkin bir şekilde iletişim içinde olabilmeyi, mesajların yüklenmesi için zamanlamayı, bilgiyi bulabilmeyi, diğerleriyle iletişim kurabilmeyi içermektedir (McMillan \& Hwang, 2002, p. 34). Ayrıca geribildirimlerin ya eş zamanlı ya da çok az bir gecikmeyle gerçekleşmesini ve böylece kurum ve hedef kitle arasında karşıııkı bir iletişim ortamının oluşturulmasını ifade etmektedir (Flew, 2002, p. 22).

Etkileşim; Facebook, Twitter, Linkedln gibi sosyal paylaşım ağları üzerinde gerçek zamanlı olarak gerçekleşmekte ve insanların kısa sürede yanıtlarını birbirlerine iletmelerini sağlayarak cevap verebilirliği olanaklı hale getirmektedir. Sosyal paylaşım ağları kullanıcıların katııımcı olma ve etkileşim içinde bulunmalarını en üst seviyeye taşımaktadır. Ayrıca kullanıııların gerçek anlamıyla etkileşim içinde olmalarını ve fikir alış verişinde bulundukları karşılıklı konuşmaların içerisine daha fazla dahil olmalarını sağlamaktadır (Kent, 2010, p. 646). Sosyal paylaşım ağlarının temelinde insanların birbirleriyle karşıııkı ilişki kurmaları ve bu ilişkileri geliştirmeleri yatmaktadır. Bu nedenle sosyal paylaşım ağları sadece kullanıcıların arasındaki ilişkileri güçlendirmemekte aynı zamanda etkileşimi de güçlendirmektedir.

Sosyal medyadaki etkileşimi arttıran sosyal paylaşım ağları bilginin hızı bir şekilde yayılmasını sağlarken, aynı zamanda hızlı değiş tokuşuna da imkân tanımaktadır (Lovejoy, Waters, \& Saxton, 2012, p. 313). Ayrıca iletişimin karşlıklı değiş tokuşunun sağlanması, anlık olması ve cevap verebilirliğin sağlanması bakımından da etkileşimin unsurlarını içinde barındırmaktadır (Kent, 2010, p. 645). 
Bugün sosyal paylaşım ağları üzerinden hedef kitlelerle etkileşim içerisinde olmak, onlara geri bildirimde bulunmak ve cevap vermek oldukça kolay bir hale gelmiştir (Vendemia, 2017, p. 101). Ancak yapılan araştırmalara göre (Bortree \& Seltzer, 2009; Yang \& Kent, 2014; Waters \& Jamal, 2011; Waters, et al., 2009), kurumların sosyal paylaşım ağlarını etkileşimli ve karşııklı iletişime dayanan bir mecra olarak kullanmada yetersiz ve başarısız oldukları ortaya çıkmaktadır. Örneğin, hedef kitlelerden gelen e-postalara kurumsal olarak cevap verilmemesi, kurumların cevap verebilirlik konusunda başarısız oldukları anlamına gelmektedir. Pek çok durumda cevap vermede başarısı olmak, cevap verebilirlikten yoksun olduğu anlamına gelirken, diğer durumlarda da zamanında cevap verilmemesi ya da kıııtlı veya işe yaramayan cevaplar verilmesi anlamına gelmektedir (Avidar, 2013, p. 442). Ayrıca sosyal paylaşım ağlarından sadece önemli bilgilerin sunulması ve halkla ilişkiler uygulamalarının bilgilendirici içeriklerinin dağıtılması da bu mecranın tek yönlü olarak kullanıldığı, etkileşimli yapısından yararlanılamadığı anlamına gelmektedir.

Oysaki sosyal paylaşım ağları; halkla ilişkiler uygulayıcılarına farklı hedef kitlelerine ve paydaşlarına ulaşmalarına ve onlarla etkileşim içine girmelerine olanak sağlamaktadır. Böylece kurumla hedef kitleler arasında karşılıklı faydaya dayalı ilişkilerin inşa edilmesi olanağı doğmaktadır (Berger \& Dong-Jin, 2003).

Sosyal medyanın etkileşimli yapısını kurumun kendi çıkarına yönelik kullanmak isteyen halkla ilişkiler uygulayıcıları, özellikle sosyal paylaşım ağları üzerinden hedef kitleden gelecek geribildirimleri almakta ve diyalog temeline dayalı iletişim çabalarını gerçekleştirmektedir.

\section{AMAÇ VE YÖNTEM}

Kurumsal iletişim amaçılı olarak Türkiye'deki hava yolları şirketlerinin Facebook kullanımlarının araştııımasını amaçlayan bu çalışma iki aşamada planlanmıştır. Araştırmanın birinci aşaması “Türkiye'deki havayolu şirketlerinin Facebook'u kurumsal amaçlı olarak kullanımı" başlığı ile araştırmacı tarafından yayımlanmıştır. Çalışmanın birinci aşaması olan adı geçen makalede Facebook'un hangi amaçla kullanıldığı ve kurumsal Facebook hesaplarından hangi tür içerikler paylaşıldığı araştııılmıştır. Çıkan sonuçlar doğrultusunda kurumların Facebook'u öncelikli olarak ürün ve hizmet tanıtımına, promosyon içerikli kampanyaların duyurulmasına yönelik kullandıkları tespit edilmiştir (Türk, 2018). 
Çalışmanın ikinci kısmı olan bu araştırma ise bir takip çalışması niteliğindedir. Facebook'un etkileşimli bir mecra olarak kullanılmasındaki yeterliliğini tespit etmeyi amaçlamaktadır. www.socialbakers.com adlı internet sitesi verilerine göre Facebook'u en aktif olarak kullanan hava yolu şirketleri arasından seçilen yerli sermayeli hava yolu şirketlerinin, Facebook'u gerçekten yoğun bir şekilde kullanıp kullanmadıklarının ortaya konması açısından önemli olarak görülmektedir. Katılımcılık, geribildirim ve cevap verebilirlik boyutlarını barındıran bir etkileşimin var olup olmadığının ortaya çıkarılması, alana katkı sağlaması bakımından önemli olarak değerlendirilmektedir.

\section{Amaç}

Facebook'un Türkiye'deki hava yolu şirketleri tarafından etkileşimli bir mecra olarak kullanılmasını ele alan bu çalışmada; Türkiye'de faaliyet gösteren yerli sermayeli havayolu şirketlerinin Facebook kullanımlarının ortaya konulması amaçlanmıştır. Bu şirketlerin; tüm dünyada olduğu gibi Türkiye'de de en yaygın ve en yoğun olarak kullanılan sosyal paylaşım ağı Facebook'un etkileşimli ve katılımcılığı sağlayan yapısından yeteri kadar yararlanıp yararlanmadıklarının belirlenmesi amaçlanmıştır. Etkileşimli bir mecra olan Facebook 'un Katılımcılık, Geribildirim ve Cevap Verebilirlik boyutlarının kurumsal iletişimdeki yeterliliğinin ortaya konmasının amaçlandığı bu devam niteliğindeki araştırmada aşağıdaki iki soruya yanıt aranmıştır:

1. Kurumlar, kullanıcıları katılımcı olmaya teşvik etmekte yeterli midir? Kullanıcıları, geribildirimde bulunmaya teşvik etmekte yeterli midir?

2. Kurumlar, kullanıcılardan gelen yorum ve sorulara cevap vermede yeterli midir? Cevap verebilirliği sağlayabilmekte midir?

\section{Yöntem}

Çalışmanın amacı doğrultusunda; altı hava yolu şirketi, betimsel araştırma yöntemlerinden içerik analizi tekniği ile analize tabi tutulmuştur.

\section{Araştırma Deseni}

İki aşamalı olarak planlanan bu araştırmanın ilk basamağı; paylaşım sıklığı, içeriği ve türü olarak tasarlanmış ve buna göre içerik analizi tekniği ile analiz edilmiştir (Türk, 2018). Çalışmanın devamı olarak ikinci basamağı olan bu çalışma ise, örneklemin 
genişletilmesi ile iki kategori üzerinden tasarlanmıştır. Buna göre ilk kategoride; şirketlerin Facebook paylaşımlarına yönelik katılımcılık ve geribildirime ilişkin değişkenler bulunurken, ikinci kategoride ise kullanıcıların yorum ve sorularına yönelik cevap verebilirliğe yönelik değişkenler bulunmaktadır (Bkz. Tablo 1).

\section{Evren ve Örneklem}

Çalışmanın evreni Türkiye'de faaliyet gösteren yerli ve yabancı sermayeli hava yolları şirketleri iken alt evreni Türkiye'de faaliyet gösteren yerli sermayeli tüm hava yolları şirketleridir. Çalışmanın örneklemini ise ilk aşamadaki çalışmanın örneklem sayısının genişletilmiş şekli olan altı hava yolu şirketi oluşturmaktadır. Bunlar; AnadoluJet, Atlasglobal, Onur Air, Pegasus Hava Yolları, SunExpress ve Türk Hava Yolları'dır. Bu hava yolu şirketleri; www.socialbakers.com adlı internet sitesinin Kasım 2016 verilerine göre Facebook'u en aktif olarak kullanan kurumlar sıralamasında ilk yirmi kurumun içerisinde yer aldıkları için örneklem olarak seçilmiştir.

\section{İşlem}

Bu çalışmada betimsel araştırma yöntemlerinden içerik analizi kullanılmıştır. İ̧̧erik analizi, belli bir metnin kitabın, belgenin, belli özelliklerini sayısallaştırarak belirleme amacı ile yapılan taramadır. Belgelerdeki belli bakış açıları, felsefeler, dil, anlatım gibi özellikler, derinliğine ve belli ölçütlere göre yapılacak çözümlemelerle anlaşılabilmektedir. İçerik çözümlemesinde sayısallaştırma ölçütlerinin önceden geliştirilmesi gerekmektedir. Bu da bir bakıma, hangi kavramların hangi sözcük ya da ifadelerle anlatılmıs olabileceğine önceden karar vermek anlamına gelmektedir. Böylece, belge; belli beklentiler (bakış açıları) ışığında incelenmektedir (Karasar, 2012, p. 184). İ̧erik analizi, araştırmacıyı toplanan verilere aşina etmekte ve ayrıca verilerin daha ileri analiz için kullanılmasını kolaylaştırmaktadır. Önceleri emek-yoğun bir şekilde bir metindeki aranan kavramların sıklıkları ölçülürken, son zamanlarda bilgisayarların ve bilgisayar destekli programların kullanılmasıyla yaygınlaşmaktadır. Iç̧erik analizi çeşitli disiplinler için yararlı olabilecek bir araştırma yöntemidir. İçerik analizinin; tarafsızlık, sistematiklik ve genellik olmak üzere üç önemli yönü vardır (Altunışık, et al., 2012, pp. 324-325).

Havayolu şirketlerinin Facebook hesapları tespit edildikten sonra, araştırmanın amacı doğrultusunda tasarlanan bilgi formlarına göre hesaplardan paylaşılan içerikler 
kodlanmıştır. Kodlama, veri toplama formundaki cevapları harf veya sayı şeklindeki sembollerle tanımlamayı ve sınıflandırmayı gerektiren bir süreçtir (Tokol, 2010, p. 98). Nitel araştırma yöntemlerinden içerik analizi tekniğinin kullanıldığı araştırmada; hava yolu şirketlerinin Facebook hesapları üzerinden toplanan veriler, betimleyici istatistiğe başvurma yoluyla analiz edilmiştir. Şirketlerinin Facebook hesaplarından paylaştıkları içerikler, paylaşılan tarihten iki gün sonra değerlendirilmeye tabi tutulmuştur. Değerlendirme sürecinde yapılan ön incelemelerde iki gün ve sonrasında paylaşımlarla ilgili değişkenlerde çok fazla farklılık olmaması nedeniyle iki gün beklenilmiştir. Kodlamalar, 60 dakikalık eğitimden sonra iki kodlayıcı tarafından gerçekleştirilmiştir ve Cronbach's Alpha kullanılarak kodlayıcı güvenirliği ( $\alpha=0.650)$ sınanmıştır. Bilgi formunda belirlenen değişkenlerden elde edilen veriler SPSS 24.0 (Statistical Package for Social Sciences for Windows) programı kullanılarak analiz edilmiştir. Analiz sonucunda değişkenlere ilişkin ortalama değer, toplam, medyan ve standart sapma değerleri saptanmıştır.

\section{BULGULAR}

Türkiye'de faaliyet gösteren yerli sermayeli altı havayolu şirketi; www.socialbakers. com internet sitesinin sıralamasına göre sıralanmıştır. Havayolu şirketlerinin kurumsal Facebook hesaplarını beğenip takip eden kullanıcıların sayısı yine web sitesinin verilerine göre; Havayolu Şirketi l'in 1.973.704; Havayolu Şirketi II'nin 1.204.726; Havayolu Şirketi III'ün 654.445; Havayolu Şirketi IV'ün 389.228; Havayolu Şirketi V'in 279.866 ve Havayolu Şirketi VI'nın 202.746'dır.

Havayolu şirketlerine ait kurumsal Facebook hesaplarının otuz günlük kodlamaya ilişkin içerik analizleri şu şekildedir:

\section{Havayolu şirketlerinin Facebook'u etkileşimli bir mecra olarak kullanımıyla ilgili kullanıcıları katılımcı olmaya teşvik etmeye ve onlardan geribildirim almaya yönelik paylaşımlarına ilişkin bulgular:}

Havayolu şirketlerinin paylaşmış oldukları fotoğraflara; kullanıcıların manşet atmak, başlık koymak gibi katkıda bulunmalarını istemesiyle ilgili paylaşımlarına bakıldığında; Havayolu Şirketi I'in fotoğrafa katkıda bulunmayı isteyen en fazla paylaşım sayısına (4) sahip olduğu görülmektedir. Havayolu Şirketi II, III, IV, V ve VI'nın ise fotoğrafa katkıda bulunmayı isteyen en az paylaşım sayısına (0) sahip olduğu 
görülmektedir (Tablo 2). Kullanıılardan kendi fotoğraflarını paylaşmalarına yönelik ve kurumla ilgili kendi anılarını ve hikâyelerinin anlattırılmasına yönelik herhangi bir paylaşımları bulunmamaktadır.

Hava yolu şirketlerinin kullanıcılarına soru sorma içerikli paylaşımlarına ilişkin veriler incelediğinde; Havayolu Şirketi l'in en fazla soru sorma içerikli (4), Havayolu Şirketi II, III ve V'in en az soru sorma içerikli paylaşım sayısına (0) sahip olduğu görülmektedir (Tablo 3). Hava yolu şirketlerinin hangi türde ve içerikli sorular sorduklarına bakıldığında ise, Havayolu Şirketi l'in paylaştığı fotoğraflara kullanıcıların katkıda bulunmasıyla ilgili sorular sorduğu; tüketim tercihi, ürün ve hizmetle ilgili sorular sormadığı görülmektedir. Sadece Havayolu Şirketi Vl, ürün ve hizmetleriyle ilgili kullanııılara doğrudan bir soru sormuştur. Havayolu Şirketi IV ise iki seçenekli bir soru yönelterek bilgiye dayalı bir soru sormuştur (Tablo 4).

Havayolu şirketlerinin incelenen otuz günlük süre zarfı içerisinde; kullanııılardan geribildirim almak amaçlı sorular sorulması, seçenekler sunarak oylatılması ve anketler paylaşarak kullanıcıların anketlere cevap vermesinin sağlanması yönündeki içeriklere ait herhangi bir paylaşımlarının olmadığı belirlenmiştir.

\section{Havayolu şirketlerinin Facebook üzerinden gelen yorum ve sorulara cevap verebilirliklerine ilişkin bulgular:}

Havayolu şirketlerinin paylaşımlarına yapılan kullanıı yorum ve sorularına ilişkin veriler incelediğinde, Havayolu Şirketi I'in en fazla yorum sayısına (852), Havayolu Şirketi V'in en az yorum sayısına (19) sahip olduğu görülmektedir (Tablo 5).

Havayolu şirketleri tarafından paylaşılan içeriklere kullanıııların yaptıkları yorumlar üzerine hava yolu şirketlerinin verdikleri cevaplara bakıldığında; Havayolu Şirketi l'in en fazla cevap sayısına (211), Havayolu Şirketi V'in en az cevap sayısına (4) sahip olduğu görülmektedir (Tablo 6). Ancak Havayolu Şirketi Il, gelen yorum sayısına göre en fazla cevap veren kurum olarak ön plana çıkmaktadır.

Havayolu şirketlerinin paylaşımlarına yapılan kullanıcı yorumlarına, kurumların verdikleri yanıtlara bakıldığında; Havayolu Şirketi I'in en fazla bilgilendirici içerikli yanıt sayısına (124), Havayolu Şirketi V ve VI'nın en az bilgilendirici içerikli yanıt sayısına (2) sahip olduğu görülmektedir (Tablo 7). Havayolu şirketlerinin kullanıcı 
yorumlarına verdikleri sorun çözücü türdeki yanıtlar incelendiğinde; Havayolu Şirketi II'nin en fazla sorun çözücü türde yanıt sayısına (36), Havayolu Şirketi V'in en az sorun çözücü türdeki yanıt sayısına (0) sahip olduğu görülmektedir (Tablo 8).

Havayolu şirketlerinin paylaşımlarına yapılan kullanıcı yorumlarına, kurumların verdikleri kısa yanıtlara bakıldığında; Havayolu Şirketi I'in en fazla kısa yanıt sayısına (79), Havayolu Şirketi II'nin en az kısa yanıt sayısına (1) sahip olduğu görülmektedir (Tablo 9).

Havayolu şirketlerinin kullanıc yorumlarına verdikleri nükteli (esprili) yanıtlara ilişkin bulgulara bakıldığında Havayolu Şirketi I ve III'ün en fazla nükteli yanıt sayısına (1), Havayolu Şirketi II, IV, V ve VI'nın en az nükteli yanıt sayısına (0) sahip olduğu görülmektedir (Tablo 10).

\section{TARTIŞMA VE SONUÇ}

Etkileşim bir yandan teknolojik olarak ortaya çıkarken diğer yandan da bu teknolojiyi kullananların bundan ne kadar yararlanabildiğiyle ilişkili olmaktadır. Yapısı itibariyle etkileşimli bir mecra olan sosyal paylaşım ağları, hedef kitlenin kurumla olan iletişiminin etkin bir şekilde gerçekleşmesine olanak tanımaktadır. Etkileşim kavramı, sosyal paylaşım ağlarının yaygın kullanımıyla birlikte özellikle son dönemlerde daha fazla ön plana çıkmış olmasına rağmen; etkileşim üzerine yapılan çalışmalar yetersiz kalmaktadır. Var olan çalışmalar da etkileşimi kurumun cevap verebilirliği algısı üzerinden ele almakta (Vendemia, 2017); etkileşimden faydalanarak sosyal medya içeriğinin etkinliğini ölçmekte (Watkins, 2017) veya etkileşimin örgütsel halkla ilişkiler niteliğine olan etkisini ele almaktadır (Saffer et al., 2013). Bu nedenle; iki aşamalı olarak planlanan çalışmanın (bkz. Türk, 2018) devamı niteliğinde olan bu çalışmada; diğer çalışmalardan farklı olarak etkileşim kavramı katılımcılık, geribildirim ve cevap verebilirlik boyutlarıyla ele alınarak alana katkı sunulmaya çalışılmıştır.

Havayolu şirketlerinin Facebook ortamında kullanıcılarını katıımcı olmaya teşvik etmesi, etkileşimin sağlanması adına önemli bir unsur olarak görülmektedir. Bu amaçla yapılacak uygulamalardan biri de paylaştıkları fotoğraflara; kullanıcıların manşet atması veya başlık koyması gibi onların bizzat katkıda bulunmalarını istemesidir. Ancak sadece bir kurumun bu doğrultuda birkaç paylaşımının olduğu, diğer kurumların herhangi bir paylaşımının olmadığı görülmektedir. Havayolu 
şirketleri Facebook üzerinde katılımcılığı sağlamada başarısız olmaları, etkileşimde katılımcılık unsurunu yerine getirememelerine neden olmaktadır.

Etkileşimin bir diğer unsuru olan geribildirim döngüsünün sağlanması adına kurumların tüketim tercihleri, ürün ve hizmetler hakkında kullanıcılarına sorular sorması gerekmektedir. Bu doğrultuda incelenen kurumların yarısı, kullanıcılarına herhangi bir soru sormamıştır. En fazla sorular yönelten havayolu şirketinin sadece fotoğraflara kullanıcıların katkıda bulunmasıyla ilgili sorular sorduğu; tüketim tercihi, ürün ve hizmetlerle ilgili hiçbir soru sormadığı belirlenmiştir. Sadece bir kurumun, ürün ve hizmetleriyle ilgili kullanıcılarına doğrudan bir soru sorduğu belirlenmiştir.

Bunun yanı sıra; kullanıcılara kurumlarıyla ilgili yaşadıkları hikâyelerin anlattırılması, onlara seçenekler sunarak oylama yaptırılması, geribildirim için sorular sorulması, anketler paylaşılarak katıımının sağlanması ve kullanıcılardan belirli konularla ilgili kendi fotoğraflarını paylaşmaya yönelik teşvik edilmesi gibi konularda herhangi bir içeriğin olmadığı belirlenmiştir. Havayolu şirketleri, kullanıcılarına geri bildirimi sağlamaya yönelik sorular sormada ve geri bildirim döngüsünün sağlanmasına yönelik kullanııları teşvik etmede oldukça yetersiz kalmaktadır.

Illetişimin değiş tokuşu ile iletişimin sağlanması ve cevap verebilirliğin yerine getirilmesi, etkileşimin sağlanmasında önemli olan diğer unsurlardandır. Kullanıcıların Facebook üzerinden havayolu şirketlerine ulaşarak yorumlarda bulundukları ve sorular sordukları görülmektedir. Kurumlar; gelen bu kullanıcı yorum ve sorularının neredeyse sadece dörtte birine cevap vermişlerdir. Yorum ve soruların dörtte üçü ise cevapsız kaldığı için kullanııılarla yeterli şekilde bir iletişim sağlanamamaktadır. Çalışmanın bu verisi, Avidar'ın (2013) çalışmasıyla benzerlik göstermektedir. Kurumların birçoğu etkiletişimin devam ettirilmesi adına potansiyel müşterileri ve üyeleri olacak kişilere yani hedef kitleye cevap verebilirliği sağlamada yetersiz kalmaktadır.

Kurumların verdikleri yanıtlar ise daha ziyade bilgi vermeye yöneliktir ve cevapların yarıdan fazlası bilgilendirici içeriklidir. Kurumlar, kullanıcılardan gelen yorum ve soruları cevaplayarak onları bilgilendirmektedir. Bu da; öğrenmek isteyen, bilgi talep eden kitlenin kurumlar tarafında dikkate alındığını ve Facebook üzerinden bu bilgi ihtiyacının karşılanmaya çalışılığını göstermektedir. 
Kurumlar ayrıca, sorun çözmeye yönelik cevaplar da vermeye çalışmakta ve bu yönde gelen soruları cevapsız bırakmamaya çalışmaktadır. Sorunları ya Facebook üzerinden çözmeye çalışmakta ya da ilgili birimlere yönlendirerek sorunun çözümü için yol göstermektedirler.

Sonuç olarak; Türkiye'de faaliyet gösteren yerli menşeli hava yolları şirketlerinin Facebook'u, etkileşimli bir mecra olarak yeteri kadar kullanamadıkları görülmektedir. Kurumlar; geribildirim döngüsünü sağlayamamakta, kullanıcıları katılımcılığa teşvik edememekte ve cevap verebilirliği yerine getirememektedirler. Oysaki etkileşimli bir mecra olan Facebook'un; kurumsal iletişimde etkileşimli bir mecra olarak kullanılmaması, akıllara hangi mecranın etkileşimli kullanıldığı sorusunu getirmektedir. Eğer Facebook etkileşimli olarak kurumlar tarafından kullanılamamaktaysa, hangi sosyal medya araçları ya da sosyal paylaşım ağları kullanılmaktadır? Geribildirim döngüsünü ve cevap verebilirliği sağlamak için kullanılan sosyal ağların ortaya çıkarılması gerekmektedir. Bu amaçlar doğrultusunda hangi sosyal ağın tercih edildiğinin ortaya çıkarılması, gelecek araştırmaların konusu olarak ortaya çıkmaktadır. Aynı şekilde Facebook'un etkileşimli olarak kullanılabilmesi için nasıl bir strateji izlenmesi gerektiğinin ortaya konulması gerekmektedir.

Bugün kişisel bilgisayarlar, akıllı telefonlar ve tabletler gibi kolaylıkla taşınabilen cihazların yaygın bir şekilde kullanılması; insanların sanal ortamlarda içerik oluşturmasını ve bu içeriklerini diğer insanlarla paylaşmasını çok daha kolay bir hale getirmiştir. Bu mobil teknolojiler sayesinde, insanlar sanal ortamlarda çok daha etkin hale gelmişler ve birbirleriyle çok daha hızlı bir şekilde etkileşim içerisinde iletişim kurmaya başlamışlardır.

Sanal ortamların başında gelen sosyal ağlar, her geçen gün yaygınlaşmakta ve önemli hale gelmektedir. Yakın gelecekte ise bu artışın daha da yoğun bir şekilde devam edeceği açıkça görülmektedir. Bu nedenle sosyal paylaşım ağlarının başında gelen Facebook'un kurumlar tarafından etkileşimli bir mecra olarak kullanılması gerekmektedir. Kurumlar eğer bunu başarabilirse, Facebook üzerinden hedef kitleleriyle karşılıklı iletişim kurabilecek ve etkileşim içerisinde olabilecektir. Böylece kurumlarla hedef kitle arasında olumlu ilişkilerin inşa edilmesi ve sürdürülmesi çok daha olanaklı hale gelecektir. 


\section{KAYNAKLAR}

Adamson, A. P. (2008). BrandDigital. New York, NY: Palgrave MacMillian.

Ariel, Y., \& Avidar, R. (2015). Information, interactivity, and social media. Atlantic Journal of Communication, 23(1), 19-30.

Altunışık, R., Coşkun R., Bayraktaroğlu S., \& Yıldııım E. (2012). Sosyal bilimlerde araştırma yöntemleri (7th ed.). Sakarya, Turkey: Sakarya Kitabevi.

Avidar, R. (2013). The responsiveness pyramid: Embedding responsiveness and interactivity into public relations theory. Public Relations Review, 39, 440-450.

Berger, B. K., \& Dong-Jin, P. (2003). Public relation(ship)s or private controls? Practitioner perspectives on the uses and benefits of new Technologies. New Jersey Journal of Communication, 11(1), 76-99.

Bortree, D. S., \& Seltzer, T. (2009). Dialogic strategies and outcomes: An analysis of environmental advocacy groups' Facebook profiles. Public Relations Review, 35(3), 317-319.

Breakenridge, D. K. (2008). PR 2.0:New media, new tools, new audiences. New Jersey, NJ: Pearson Education.

Brubaker, P. J., \& Wilson, C. (2018). Let's give them something to talk about: Global brands' use of visual content to drive engagement and build relationships. Public Relations Review,44, 342-352.

Davis D. (1982). Determinants of responsiveness in dyadic interaction. In W. Ickes \& E. S. Knowles (Eds.), Personality, roles, and social behavior (pp. 85-139). New York, NY: Springer.

Oxford Dictionaries. (2017). Etkileşimin tanımı. Retrieved from http://www.oxforddictionaries.com/ definition/ english/interactivity

Facebook. (2017a). Facebook istatistikleri. Retrieved from https://newsroom.fb.com/company-info/ Facebook. Facebook. (2017b). Facebook özellikleri. Retrieved from http://newsroom.fb.com/products/

Flew, T. (2002). New media: An introduction. Oxford, UK: Oxford University Press.

Freeman, B., \& Chapman, S. (2012). Measuring interactivity on tobacco control websites. Journal of Health Communication, 17(7), 857-865.

Grunig, J. E. (2002). Qualitative methods for assessing relationships between organizations and publics. Retrieved from https://www.instituteforpr.org//wp-content/uploads/2002_AssessingRelations.pdf

Grunig, J. E. (2009). Paradigms of global public relations in an age of digitilization. PRism, 6(2), 1-19.

Grunig, J. E., \& Grunig, A. (1992). Models of public relations and communication. In J. E. Grunig, D. M. Dozier, W. P. Ehling, L. A. Grunig, F. C. Repper \& J. White (Eds.), Excellence in public relations and communication management (pp. 285-325). Hillsdale, NJ: Lawrence Erlbaum Associates.

Handley, A., \& Chapman, C. C. (2011). Content rules: How to create killer blogs podcasts, videos, ebooks, webinars (and more) that engage customers and ignite business. Hoboken, NJ: John Wiley \& Sons.

Hether, H. J. (2014). Dialogic communication in the health care context: A case study of Kaiser Permanente's social media practices. Public Relations Review, 40, 856-858.

Hopkins, M. (2012). The planetary bargain: Corporate social responsibility matters. London, UK: Routledge. 
Karakoç, E., \& Gülsünler, M. (2012). Kullanımlar ve doyumlar yaklaşımı bağlamında Facebook: Konya üzerine bir araştırma. Akdeniz Iletişim, 18, 43-57.

Karasar, N. (1984). Bilimsel araştırma yöntemi, kavramlar - ilkeler - teknikler (23rd ed.). Ankara, Turkey: Nobel Yayınevi.

Kelleher, T., \& Miller, B. M. (2006). Organizational blogs and the human voice: Relational strategies and relational outcomes. Journal of Computer Mediated Communication, 11(2), 395-414.

Kent, M. L. (2010). Directions in social media for professionals and scholars. In R. Heath (Ed.), The Sage handbook of public relations, (pp. 643-655), Thousand Oaks, CA: Sage.

Kent, M. L., \& Taylor, M. (1998). Building dialogic relationships through the world wide web. Public Relaitons Review, 24(3), 321-334.

Kent, M. L., \& Taylor, M. (2002). Toward a dialogic theory of public relations. Public Relations Review, 28(1), 21-37.

Kent, M. L., Taylor, M., \& White, W. (2003). The relationship between web site design and organizational responsiveness to stakeholders. Public Relations Review, 29, 66-77.

Kiousis, S. (2002). Interactivity: A concept explication. New Media \& Society, 4(3), 355-383.

Lange, P. G. (2007). Publicly private and privately public: Social networking on YouTube. Journal of ComputerMediated Communication, 13(1), 361-380.

Lipsman, A., Graham, M., Mike, R., \& Sean, B. (2012). The power of "like". Journal of Advertising Research, 52(1), 40-52.

Lovejoy, K., Waters, R. D., \& Saxton, G. D. (2012). Engaging stakeholders through Twitter: How nonprofit organizations are getting more out of 140 characters or less. Public Relations Review, 38(2), 313-318.

McAllister-Spooner, S. M. (2009). Fulfilling the dialogic promise: A ten-year reflective survey on dialogic Internet principles. Public Relations Review, 35, 320-322.

McMillan, S. J. (2002). A Four-part model of cyber-ınteractivity. New Media \& Society, 4(2), 271-291.

McMillan, S. J., \& Hwang, J. S. (2002). Measures of perceived interactivity: An exploration of the role of direction of communication, user control, and time in shaping perceptions of interactivity. Journal of Advertising, $31(3), 29-42$.

Men, L. R., \& Tsai, W. S. (2014). Perceptual, attitudinal, and behavioral outcomes of organization-public engagement on corporate social networking sites. Journal of Public Relations Research, 26(5), 417-435.

Newhagen, J. E. (2004). Interactivity, dynamic symbol processing and the emergence of content in human communication. The Information Society, 20, 393-396.

Quiring, O. (2009). What do users associate with 'interactivity'?: A qualitative study on user schemata. New Media \& Society, 11(6), 899-920.

Powell, T. E., Boomgaarden, H. G., De Swert, K., \& de Vreese, C. H. (2015). A clearer picture: The contribution of visuals and text to framing effects. Journal of Communication, 65(6), 997-1017.

Rafaeli, S. (1988). Interactivity. From new media to communication. In R. P. Hawkins, J. M. Wiemann \& S. Pingree (Eds.), Advancing communication science: Merging mass and interpersonal processes (pp. 110-134). Newbury Park, CA: Sage. 
Rafaeli, S., \& Ariel, Y. (2007). Assessing interactivity in computer-mediated research. In A. N. Joinson, K. Y. A. McKenna, T. Postmes \& U. D. Reips (Eds.), The Oxford handbook of Internet psychology (pp. 71-89). Oxford, UK: Oxford University Press.

Reber, B. H., \& Kim, J. K. (2006). How activist groups use websites in media relations: Evaluating online press rooms. Journal of Public Relations Research, 18, 313-333.

Richards, R. (2006). Users, interactivity and generation. New Media \& Society, 8(4), 531-550.

Saffer, A. J., Sommerfeldt, E. J., \& Taylor, M. (2013). The effects of organizational Twitter interactivity on organization-public relationships. Public Relations Review, 39, 213-215.

Şener, G. (2009). Türkiye'de Facebook kullanımı araştırması. inet-tr'09 - XIV. Türkiye'de Internet Konferansı Bildirileri, İstanbul, Turkey.

Theunissen, P., \& Wan Noordin, W. N. (2012). Revisiting the concept "dialogue" in public relations. Public Relations Review, 38(1), 5-13.

Tufan, F. (2014). New possibilities provided by social networks to radio broadcasting practices: R@DIO 2.0. Journal of Media Critiques, 1, 87-101.

Tokol, T. (2010). Pazarlama Araştırması. Bursa, Turkey: Dora Yayıncılık.

Türk, E. (2018). Türkiye'deki havayolu şirketlerinin Facebook'u kurumsal amaçlı olarak kullanımı. Gümüşhane Üniversitesi Illetişim Fakültesi Elektronik Dergisi, 6, 1277-1298.

Vendemia, M. A. (2017). When do consumers buy the company? Perceptions of interactivity in companyconsumer interactions on social networking sites. Computers in Human Behavior, 71, 99-109.

Waters, R. D., Burnett, E., Lamm, A., \& Lucas, J. (2009). Engaging stakeholders through social networking: How nonprofit organizations are using Facebook. Public Relations Review, 35, 102-106.

Waters, R. D., \& Jamal, J. Y. (2011). Tweet, tweet, tweet: A content analysis of nonprofit organizations' Twitter updates. Public Relations Review, 37, 321- 324.

Waters, R. D., \& Williams, J. M. (2011). Squawking, tweeting, cooing, and hooting: Analyzing the communication patterns of government agencies on Twitter. Journal of Public Affairs, 11(4), 353-363.

Watkins, B. A. (2017). Experimenting with dialogue on Twitter: An examination of the influence of the dialogic principles on engagement, interaction, and attitude. Public Relations Review, 43, 163-171.

Wright, D. K., \& Drifka, M. (2009). An analysis of the increasing impact of social and other new media on public relations practice. 12th Annual International Public Relations Research Conference, Miami, Florida.

Yang, A., \& Taylor, M. (2010). Relationship building by Chinese ENGO's websites: Education, not activation. Public Relations Review, 36(4), 342-351. 


\section{TABLOLAR}

\section{Tablo 1: Facebook Hesaplarının İçerik Analizinde Kullanılan Değişkenler}

\begin{tabular}{|c|c|}
\hline \multicolumn{2}{|r|}{ Değişkenler } \\
\hline \multirow{9}{*}{$\begin{array}{l}\text { Katılımcılığa ve } \\
\text { geribildirime ilişkin } \\
\text { değişkenler: }\end{array}$} & $\begin{array}{l}\text { Manşet Atmak, Başlık Koymak Gibi Kullanıııların Fotoğraflara Katkıda } \\
\text { Bulunmalarını İstemesi }\end{array}$ \\
\hline & Kullanıcılardan Kendi Fotoğraflarını Paylaşmasını İsteyen Soruların Sayısı \\
\hline & Kurumla Illgili Anıların, Hikâyelerin Anlattırılması \\
\hline & Kullanıcılara Soru Sorma İçerikli Paylaşımların Sayısı \\
\hline & Geribildirim Amaçlı Soruların Sayısı \\
\hline & Tüketim Tercihiyle İlgili Soruların Sayısı \\
\hline & Ürün ve Hizmetin Kendisiyle İlgili Soruların Sayısı \\
\hline & Geribildirim Amaçlı Anket Şeklindeki Soruların Sayısı \\
\hline & Geribildirim Amacıyla Kullanııılara Seçenekler Sunarak Oylatma Yapılması \\
\hline \multirow{6}{*}{$\begin{array}{l}\text { Yorum ve sorulara } \\
\text { cevap verebilirliğe } \\
\text { ilişkin değişkenler: }\end{array}$} & Kullanıcı Yorumlarının Sayısı \\
\hline & Kurumların Verdikleri Cevapların Sayısı \\
\hline & Kurumların Bilgi Vermeye Yönelik Cevaplarının Sayısı \\
\hline & Kurumların Sorun Çözmeye Yönelik Cevaplarının Sayısı \\
\hline & Kurumların Verdikleri Kısa Cevapların Sayısı \\
\hline & Kurumların Verdikleri Nükteli/Esprili Cevapların Sayısı \\
\hline
\end{tabular}

Tablo 2: Havayolu Şirketlerinin Paylaştıkları Fotoğrafa Kullanıcıların Katkıda Bulunmasını (Manşet atmak, başlık koymak vb.) İsteyen Paylaşımların Sayılarına îlişkin Bulgular

\begin{tabular}{|l|c|c|c|c|c|c|}
\hline \multicolumn{1}{|c|}{ Havayolları Şirketleri } & Orta. & Top. & Min. & Mak. & Med. & St. Sapma \\
\hline Havayolu Şirketi I &, 13 & 4 & 0 & 2 & 0 &, 43 \\
\hline Havayolu Şirketi II & 0 & 0 & 0 & 0 & 0 & 0 \\
\hline Havayolu Şirketi III & 0 & 0 & 0 & 0 & 0 & 0 \\
\hline Havayolu Şirketi IV & 0 & 0 & 0 & 0 & 0 & 0 \\
\hline Havayolu Şirketi V & 0 & 0 & 0 & 0 & 0 & 0 \\
\hline Havayolu Şirketi VI & 0 & 0 & 0 & 0 & 0 & 0 \\
\hline
\end{tabular}

\section{Tablo 3: Havayolu Şirketlerinin Soru Sorma Sayılarına İlişkin Bulgular}

\begin{tabular}{|l|c|c|c|c|c|c|}
\hline \multicolumn{1}{|c|}{ Havayolları Şirketleri } & Orta. & Top. & Min. & Mak. & Med. & St. Sapma \\
\hline Havayolu Şirketi I &, 13 & 4 & 0 & 2 & 0 &, 434 \\
\hline Havayolu Şirketi II & 0 & 0 & 0 & 0 & 0 & 0 \\
\hline Havayolu Şirketi III & 0 & 0 & 0 & 0 & 0 & 0 \\
\hline Havayolu Şirketi IV &, 03 & 1 & 0 & 1 & 0 &, 18 \\
\hline Havayolu Şirketi V & 0 & 0 & 0 & 0 & 0 & 0 \\
\hline Havayolu Şirketi VI &, 03 & 1 & 0 & 1 & 0 &, 18 \\
\hline
\end{tabular}


Tablo 4: Havayolu Şirketlerinin Ürünleriyle İlgili Soru Sorma Sayılarına İlişkin Bulgular

\begin{tabular}{|l|c|c|c|c|c|c|}
\hline \multicolumn{1}{|c|}{ Havayolları Şirketleri } & Orta. & Top. & Min. & Mak. & Med. & St. Sapma \\
\hline Havayolu Şirketi I & 0 & 0 & 0 & 0 & 0 & 0 \\
\hline Havayolu Şirketi II & 0 & 0 & 0 & 0 & 0 & 0 \\
\hline Havayolu Şirketi III & 0 & 0 & 0 & 0 & 0 & 0 \\
\hline Havayolu Şirketi IV & 0 & 0 & 0 & 0 & 0 & 0 \\
\hline Havayolu Şirketi V & 0 & 0 & 0 & 0 & 0 & 0 \\
\hline Havayolu Şirketi VI &, 03 & 1 & 0 & 1 & 0 &, 18 \\
\hline
\end{tabular}

Tablo 5: Havayolu Şirketlerinin Paylaşımlarına Yapılan Kullanıcı Yorumlarının Sayılarına İlişkin Bulgular

\begin{tabular}{|l|c|c|c|c|c|c|}
\hline \multicolumn{1}{|c|}{ Havayolları Şirketleri } & Orta. & Top. & Min. & Mak. & Med. & St. Sapma \\
\hline Havayolu Şirketi I & 28,40 & 852 & 0 & 120 & 15,50 & 33,39 \\
\hline Havayolu Şirketi II & 14,13 & 424 & 0 & 138 & 0 & 31,01 \\
\hline Havayolu Şirketi III & 1,97 & 60 & 0 & 9 & 0 & 2,67 \\
\hline Havayolu Şirketi IV & 4,67 & 143 & 0 & 46 & 2,50 & 9,09 \\
\hline Havayolu Şirketi V &, 63 & 19 & 0 & 8 & 0 & 1,77 \\
\hline Havayolu Şirketi VI & 1,20 & 36 & 0 & 18 & 0 & 4,08 \\
\hline
\end{tabular}

Tablo 6: Havayolu Şirketleri Tarafından Paylaşılan İçeriklere Kullanıcıların Yorumları Üzerine Hava Yolu Şirketlerinin Verdikleri Cevap Sayılarına Iilişkin Bulgular

\begin{tabular}{|l|c|c|c|c|c|c|}
\hline \multicolumn{1}{|c|}{ Havayolları Şirketleri } & Orta. & Top. & Min. & Mak. & Med. & St. Sapma \\
\hline Havayolu Şirketi I & 7,03 & 211 & 0 & 34 & 5 & 8,77 \\
\hline Havayolu Şirketi II & 4,90 & 147 & 0 & 44 & 0 & 10,94 \\
\hline Havayolu Şirketi III &, 53 & 16 & 0 & 5 & 0 & 1,13 \\
\hline Havayolu Şirketi IV & 1,33 & 40 & 0 & 8 & 0 & 2,21 \\
\hline Havayolu Şirketi V &, 13 & 4 & 0 & 1 & 0 &, 34 \\
\hline Havayolu Şirketi VI &, 27 & 8 & 0 & 5 & 0 &, 98 \\
\hline
\end{tabular}

Tablo 7: Havayolu Şirketlerinin Paylaşımlarına Yapılan Kullanıcı Yorumlarına Verilen Bilgilendirici Yanıtlara İlişkin Bulgular

\begin{tabular}{|l|c|c|c|c|c|c|}
\hline \multicolumn{1}{|c|}{ Havayolları Şirketleri } & Orta. & Top. & Min. & Mak. & Med. & St. Sapma \\
\hline Havayolu Şirketi I & 4,13 & 124 & 0 & 16 & 2,50 & 5,05 \\
\hline Havayolu Şirketi II & 3,67 & 110 & 0 & 43 & 0 & 10,11 \\
\hline Havayolu Şirketi III &, 30 & 9 & 0 & 3 & 0 &, 79 \\
\hline Havayolu Şirketi IV &, 97 & 29 & 0 & 7 & 0 & 1,83 \\
\hline Havayolu Şirketi V &, 07 & 2 & 0 & 1 & 0 &, 25 \\
\hline Havayolu Şirketi VI &, 07 & 2 & 0 & 1 & 0 &, 25 \\
\hline
\end{tabular}


Tablo 8: Havayolu Şirketlerinin, Kullanıcı Yorumlarına Verdikleri Sorun Çözücü Yanıtlara İlişkin Bulgular

\begin{tabular}{|l|c|c|c|c|c|c|}
\hline \multicolumn{1}{|c|}{ Havayolları Şirketleri } & Orta. & Top. & Min. & Mak. & Med. & St. Sapma \\
\hline Havayolu Şirketi I &, 23 & 7 & 0 & 3 & 0 &, 62 \\
\hline Havayolu Şirketi II & 1,20 & 36 & 0 & 6 & 0 & 1,91 \\
\hline Havayolu Şirketi III &, 07 & 2 & 0 & 1 & 0 &, 25 \\
\hline Havayolu Şirketi IV &, 17 & 5 & 0 & 2 & 0 &, 46 \\
\hline Havayolu Şirketi V & 0 & 0 & 0 & 0 & 0 & 0 \\
\hline Havayolu Şirketi VI &, 03 & 1 & 0 & 1 & 0 &, 18 \\
\hline
\end{tabular}

Tablo 9: Havayolu Şirketlerinin Paylaşımlarına Yapılan Kullanıcı Yorumlarına Kurumların Verdikleri Kısa Yanıtlara İlişkin Bulgular

\begin{tabular}{|l|c|c|c|c|c|c|}
\hline \multicolumn{1}{|c|}{ Havayolları Şirketleri } & Orta. & Top. & Min. & Mak. & Med. & St. Sapma \\
\hline Havayolu Şirketi I & 2,63 & 79 & 0 & 20 & 1,50 & 4,19 \\
\hline Havayolu Şirketi II &, 03 & 1 & 0 & 1 & 0 &, 18 \\
\hline Havayolu Şirketi III &, 13 & 4 & 0 & 2 & 0 &, 43 \\
\hline Havayolu Şirketi IV &, 20 & 6 & 0 & 1 & 0 &, 40 \\
\hline Havayolu Şirketi V &, 07 & 2 & 0 & 1 & 0 &, 25 \\
\hline Havayolu Şirketi VI &, 17 & 5 & 0 & 3 & 0 &, 59 \\
\hline
\end{tabular}

Tablo 10: Havayolu Şirketlerinin Paylaşımlarına Yapılan Kullanıcı Yorumlarına Verilen Nükteli Yanıtlara İlişkin Bilgiler

\begin{tabular}{|l|c|c|c|c|c|c|}
\hline \multicolumn{1}{|c|}{ Havayolları Şirketleri } & Orta. & Top. & Min. & Mak. & Med. & St. Sapma \\
\hline Havayolu Şirketi I &, 03 & 1 & 0 & 1 & 0 &, 18 \\
\hline Havayolu Şirketi II & 0 & 0 & 0 & 0 & 0 & 0 \\
\hline Havayolu Şirketi III &, 03 & 1 & 0 & 1 & 0 &, 18 \\
\hline Havayolu Şirketi IV & 0 & 0 & 0 & 0 & 0 & 0 \\
\hline Havayolu Şirketi V & 0 & 0 & 0 & 0 & 0 & 0 \\
\hline Havayolu Şirketi VI & 0 & 0 & 0 & 0 & 0 & 0 \\
\hline
\end{tabular}

